\title{
Intercropping of Coffee with Enset (Enset ventricosum Welw. Cheesman) at Teppi, Southwestern Ethiopia
}

\author{
Behailu Mekonnen*, Essubalew Getachew, Shiferaw Temteme, Tesfaye Shimber, Anteneh \\ Netsere \\ Teppi Agricultural Research Center, Teppi, Ethiopia.
}

*Corresponding Authors: Behailu Mekonnen, Teppi Agricultural Research Center, Teppi, Ethiopia.

\begin{abstract}
Intercropping is an excellent system of cropping which achieves a diversified and intensified crop production through better utilization of growth resources and inputs. An experiment was conducted at Teppi Agricultural Research Center from 2011 to 2015 cropping calendar to determine optimum intercropping ratios of coffee and enset that enhances yield productivity and land-use efficiency. The study consisted of six treatments viz., sole cropping of each crop, a staggered planting of both crops, 1:1, 2:1, 3:1 row ratios of coffee to enset, respectively. The experiment was laid out in a randomized complete block design with three replications. A lowland coffee variety (Catimor J-19) and local enset variety were used. The result revealed that the growth parameters of both coffee and enset were not significantly influenced by intercropping, except the internode length of coffee primary branches. However, the yields of the component crops were significantly $(p \leq 0.05)$ affected by different ratios of intercropping. The maximum clean coffee yield was obtained from the sole coffee plot $\left(1127.68 \mathrm{~kg} \mathrm{ha}^{-1}\right)$ followed by the staggered plot (1082.04 $\left.\mathrm{kg} \mathrm{ha}^{-1}\right)$. Similarly, the highest kocho $(44167 \mathrm{~kg}$ $\left.\mathrm{ha}^{-1}\right)$ and bulla $\left(1734.70 \mathrm{~kg} \mathrm{ha}^{-1}\right)$ yields were also found from the sole enset plot. On the other hand, the combined yields of the component crops in all intercropped plots were higher than the sole plots and the LER value was greater than 1. The maximum relative yield advantage of coffee and LER value was recorded from the staggered plot followed by the plot consists of a 3:1 row ratio of coffee to enset. In general, the result was disclosed the agronomic feasibilities of coffee and enset intercropping and the compatibility of the component crops as well. Therefore, it can be concluded that staggered planting of coffee and enset is a suitable cropping arrangement for enhancing the yield productivity of the component crops and ensuring food security for the resource-poor farmers. Thus, the aforementioned planting arrangement can be recommended for farmers and growers in the study area. Nevertheless, additional researches are required in different agro-ecologies of the country with economic feasibility studies to deliver a concrete recommendation.
\end{abstract}

Keywords: Coffee, Enset, Intercropping, Land equivalent ratio, Yield advantage

\section{ABBREVIATIONS}

LER - Land Equivalent Ratios

TARC - Teppi Agricultural Research Center

M.A.S.L - Meter Above Sea Level

$\mathrm{pH}$ - Power of Hydrogen

SAS - Statically Analysis Software

LSD - Least Significance Difference

\section{INTRODUCTION}

In Ethiopia, coffee is the major cash crop that plays a significant role in the household as well as regional and national economies. Although it is considered mainly as a cash crop, it is also highly consumed all over the country [1]. Coffee intercropping is an old practice, which could probably have emerged from the indigenous knowledge of coffee existence as an understory crop in its native land, Ethiopia. According to [2], the crop is commonly grown as a garden plantation being intercropped with different crops such as banana, enset, and some other fruit crops. Besides, it is also possible to interplant citrus, enset, avocado with coffee to improve the household income as reported by [3], [4] and [5]. The coffeebased intercropping system provides an improved farm earning for smallholder farmers without an adverse impact on the yield and quality of coffee [6, 7]. Besides, it helps to protect the soil from erosion, crop diversification, providing shade, control coffee diseases and frost effects [8,9], improves the soil 
fertility through the provision of in situ mulch [10], and recycles more nutrients and sustainable intensification of small plots [11]. Also, the system increased resilience to drought and extreme weather events, and natural resource integrity, reducing the risk of coffee price fluctuations, improving farm earning, and ensuring food security [6, 7, and 12].

Like coffee, enset is also a major multi-purpose crop in Ethiopia, which has been identified as the center of origin and diversity of enset [13,14]. According to [15], the crop is widely grown in the home gardens of central, south, and southwestern parts of Ethiopia for its food, forage, fiber, and medicinal uses. The major foods obtained from enset are kocho and bulla, which are obtained from pseudo stem and leaf petioles [16]. According to [17] and [18], the crop serves as a traditional staple food and supplemented with cereals for more than $20 \%$ of Ethiopia's population particularly in the southern, southwestern and central part of the country. The farming system of the southern and southwestern parts of the country is commonly characterized by growing of two or more complementary crop species. In these potential areas, enset usually intercropped with perennial tree crops viz., coffee, avocado, citrus and other fruit crops under the home garden and main field conditions as reported by several authors $[14,15]$. In addition, [4] and [5] also suggested that avocado, banana, and coffee crops are highly preferable to grow in the mixture with enset, particularly in the southern and southwestern part of the country. This helps the local farmers to exploit the growth resources thereby getting sufficient food for their families and good returns.

However, the increased population pressure and subdivision of farms have led to the fragmentation of land, and reduction of area coverage of different crops. For instance, more than $95 \%$ of the country's agricultural output is generated by subsistence farmers who, on average, own less than one hectare of cultivated land [19]. Therefore, the alert of the small farm size owned by farmers, the prolonged time and shade requirements of coffee trees for crop bearing, intercropping is the only remedy to increase the productivity of the component crops and land-use efficiency. It has been also reported that the diversification of coffee with compatible crop types would be the right option for better resource use efficiency and productivity [4, 5, 20 and 21]. Despite its economic and social advantage, the effects of coffee-enset intercropping on the yield productivity of the component crops have not been studied yet. Besides, detailed information's on the ratios of intercropping and their interaction were required for coffee-enset based grown areas including the study site. Accordingly, this study was proposed to determine biologically optimum intercropping ratios between coffee and enset that can enhance the land-use efficiency and yield productivity of the component crops at Teppi, Southwestern Ethiopia.

\section{MATERIALS AND METHODS}

\subsection{Site Description, Soil Properties, and Meteorological Data}

The experiment was conducted at Teppi Agricultural Research Center (TARC) from the year 20112015. The center is located at $7^{0} \quad 10^{\prime} \mathrm{N}$ latitude and $35^{\circ} \quad 25^{\prime} \mathrm{E}$ longitude (https://earth.google.com/web/@ 48.85543824,2.36282506,35.18886965a,25.00073194d,35y,0h,0t,0r) and situated at an altitude of 1200 m.a.s.l, representing a lowland altitude according to Ethiopian traditional agro-ecological division, the elevation is the basis for this classification [22]. It is characterized by hot humid with an average annual rainfall of $1559 \mathrm{~mm}$, and a mean maximum and minimum temperature of $30.23{ }^{\circ} \mathrm{C}$ and $16.09{ }^{\circ} \mathrm{C}$, respectively [23]. The soil type of the experimental site is classified as Nitisols, which is dominated by a loam texture with a $\mathrm{pH}$ range of 5.60 to 6.0 [24]. The soil depth is very deep $(>150 \mathrm{~cm})$ and has a color of dark brown $(7.5 \mathrm{YR} 3 / 2)$ when moist. The organic matter content is medium to very high $(2.47$ to $7.02 \%)$ according to [25] classification. The total nitrogen content is low to very high $(0.09$ to $0.73 \%)$ according to [26] classification, while the available phosphorus is low to medium (0.97 to $7.36 \mathrm{ppm})$ based on the rating of [27]. The meteorological data for the years 2011 to 2015 were obtained from Teppi Agricultural Research Center and presented in Table 1 and Figure 1.

\begin{tabular}{|c|c|c|c|c|c|c|c|c|c|c|}
\hline \multirow{2}{*}{ Month } & \multicolumn{2}{|c|}{2011} & \multicolumn{2}{|c|}{2012} & \multicolumn{2}{|c|}{2013} & \multicolumn{2}{|c|}{2014} & \multicolumn{2}{|c|}{2015} \\
\hline & Min. & Max. & Min. & Max. & Min. & Max. & Min. & Max. & Min. & Max. \\
\hline Jan & 13.4 & 31.5 & 13.9 & 31.3 & 11.7 & 31.8 & 12.3 & 33.6 & 13.5 & 29.3 \\
\hline Feb & 14.6 & 34.2 & 12.8 & 32.2 & 13.7 & 34.7 & 13.7 & 34.2 & 12.9 & 30.6 \\
\hline March & 16.7 & 32.9 & 15.3 & 33.2 & 15 & 33.4 & 14.8 & 32.6 & 14.6 & 32.7 \\
\hline April & 17 & 31.6 & 15.8 & 30.3 & 15.7 & 31.7 & 15.3 & 30.6 & 16.5 & 30.7 \\
\hline May & 16.7 & 30.6 & 15.5 & 29.6 & 15.3 & 29 & 14.8 & 29 & 16.2 & 29.1 \\
\hline Jun & 15.6 & 28.1 & 15.2 & 28.2 & 15.4 & 28.4 & 14.4 & 28.6 & 15.6 & 27.5 \\
\hline Jul & 15.2 & 26.5 & 14.4 & 27.5 & 15 & 27.2 & 14.9 & 27.4 & 15.6 & 27.1 \\
\hline Aug & 15.3 & 26.8 & 14.5 & 27.9 & 14.8 & 28.2 & 14.4 & 27.4 & 15.3 & 26.9 \\
\hline Sep & 15.1 & 28.5 & 14.6 & 28.2 & 15 & 28.3 & 14.4 & 27.2 & 15.1 & 27.8 \\
\hline Oct & 14.2 & 30.2 & 13.3 & 30.1 & 13.9 & 29.2 & 14.4 & 29.3 & 14.25 & 28.85 \\
\hline Nov & 13.4 & 30 & 13.5 & 29.4 & 12.3 & 30.4 & 14.4 & 28.4 & 13.1 & 30.1 \\
\hline Dec & 12.6 & 30.1 & 13.4 & 29.7 & 9.4 & 33.1 & 14.4 & 28.6 & 11.3 & 31.2 \\
\hline
\end{tabular}




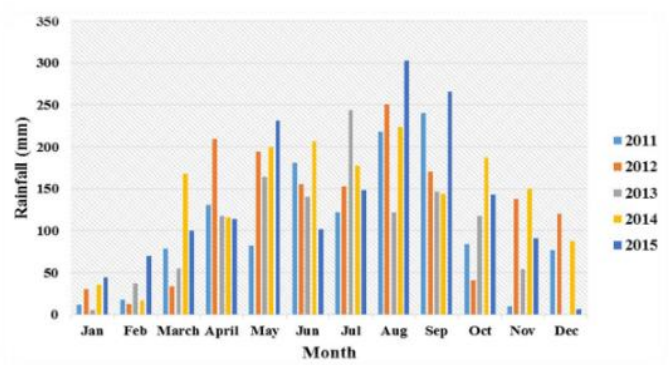

Figure1. Monthly rainfall ( $\mathrm{mm}$ ) of the study area (2011-2015)

\subsection{Experimental Structure, Planting Materials, and Crop Husbandry}

The treatments included sole stands of coffee and enset, four intercropping ratios of coffee and enset viz., coffee and enset in alternate rows (1:1), 2 rows of coffee to a row of enset (2:1), 3 rows of coffee to a row of enset (3:1), and a staggered planting of coffee with enset (i.e. four coffee trees were planted alternatively around the enset tree). The experiment was laid out in a randomized complete block design with three replications. Coffee seedlings were planted at a spacing of $2 \mathrm{~m} \times 2 \mathrm{~m}$ both in the sole and intercropped plots, it was also planted in staggered fashion between rows of enset tree with the aforementioned spacing. One-year-old seedlings of local enset clone were planted on the field at the end of March when the rainfall was started at a spacing of $3 \mathrm{~m} \times 2 \mathrm{~m}$ and $2 \mathrm{~m} \times 2 \mathrm{~m}$ in the sole and intercropped plots, respectively. Enset seedlings were transplanted in April 2011, the second round was transplanted in April 2013 before harvesting of the first round to retain its shade for the grown coffee. Whereas, the coffee seedlings were planted in June 2011 based on the above-mentioned spacing accordingly. Among the lowland coffee variety (Catimor J-19) and local enset variety were used for this study. Coffee trees were trained in single stem and capped at $2 \mathrm{~m}$ height, undesirable laterally grown of branches and suckers were removed throughout the study. Except for the experimental variables, other field and crop management practices were applied for both crops as of the recommendation [5, $28,29]$.

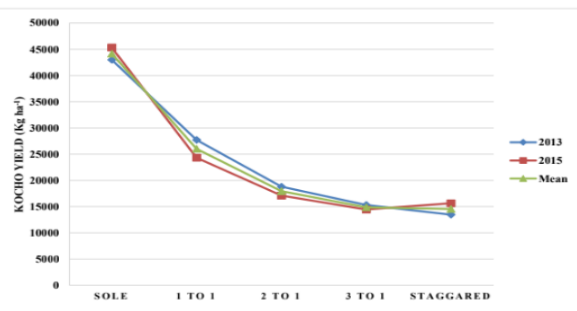

Figure2a. The relative yields of kocho as influenced by intercropping ratios of coffee and enset at Teppi in 2013 and 2015 harvesting seasons

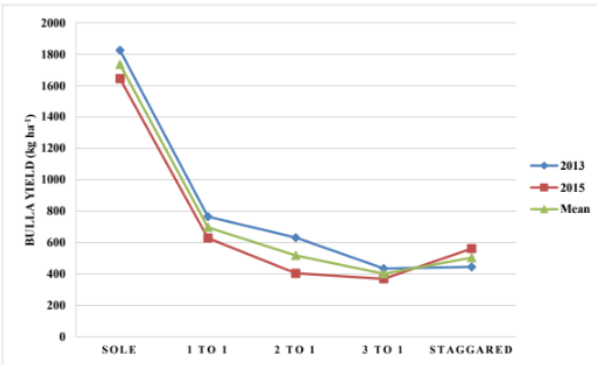

Figure2b. The relative yields of bulla as influenced by intercropping ratios of coffee and enset at Teppi in 2013 and 2015 harvesting seasons

\subsection{Data Collection and Crop Harvests}

Data on growth, yield, and yield-related traits of coffee were recorded from representative sample trees as per the scheduled periods, the sample trees were randomly selected only from the central rows of each experimental plots. With regard to enset, the yield and yield-related traits of enset data were recorded in 2013 and 2015 cropping seasons since the crop needs two and half years for its maturation. Alike coffee, the enset data were recorded from randomly selected sample plants of each experimental plot. Although enset is usually harvested just before flowering, the preferred harvesting time is just when the plant flowers as reported by [30]. Accordingly, the enset plant was harvested when flowering starts and the yield was measured by taking the weight of the processable pseudo stem after the leaves and un-processable parts of the pseudo stems were removed. The pseudo-stem was also decorticated to separate the cortex from the fiber, after that the cortex was chopped to pieces. Besides, the corm was 
also up-rooted, chopped, and added to the yield. Finally, the total weight was measured and preserved for 15 days of fermentation. After checking the fermented yield for its maturity, it was squeezed and measured their retrieval weights as dry kocho and wet bulla yields.

\subsection{Land Equivalent Ratio (LER)}

The productivity of the intercropping system in terms of the land equivalent ratio (LER) was used [3135], in order to measure the yield advantage of coffee-enset based cropping over the sole crops. Thus, LER was calculated by using the following formula;

Land Equivalent Ratio $($ LER $)=\left(\frac{Y i j}{Y i \boldsymbol{i}}\right)+\left(\frac{\boldsymbol{Y} \boldsymbol{j i}}{\boldsymbol{Y} \boldsymbol{j} \boldsymbol{j}}\right)$

Where, $Y$ is the yields of component crops per unit area, $Y i i$ and $Y j j$ sole crop yield of coffee and enset and $Y i j$ and $Y j i$ are intercropped yields of coffee and enset, respectively. When the value of LER shows $>1$, the intercropping system favors the growth and yield of the component crops. In contrast, if the value of LER demonstrates $<1$, the intercropping system negatively affects the growth and yield of the component crops grown in mixtures [36]. Besides, the interspecific competition becomes stronger compared with the interspecific interaction within the intercropping system when the value of LER $<1$ [37].

\subsection{Data Analysis}

The collected data were subjected to statistical analysis. Analyses of variance were carried out using SAS version 9.2 English [38]. Significant differences between and or among treatments were delineated by Least Significant Differences (LSD) at 5\% probability [39].

\section{RESULTS AND DISCUSSIONS}

\subsection{Coffee}

The analysis of variance of this study revealed that the growth parameters of coffee were not significantly influenced by coffee-enset intercropping ratios in the course of the study period. However, the clean coffee yield was significantly $(p<0.05)$ influenced by different planting ratios of coffee and enset intercropping. In all harvesting seasons, the clean coffee yield of the sole and staggered plots was significantly different from clean coffee yields obtained from intercropped plots, except the plot having with 3:1 coffee to enset ratio in 2013 and 2014 harvesting seasons. Accordingly, the highest clean coffee yield in 2014 and 2015 harvesting seasons were obtained from a staggered planted coffee followed by a solely planted coffee, but in 2013 the highest clean coffee yield was found from a solely planted coffee (Table 2). On the contrary, the lowest clean coffee yield was recorded at an equal (1:1 coffee to enset) intercropping ratio throughout the study period. Similarly, the mean yields of the clean coffee were also influenced by the different planting ratios of coffee and enset intercropping. Thus, the highest and lowest clean coffee yields were found from a solely planted coffee followed by a staggered planted coffee and from equally (1:1 coffee to enset) planted coffee, respectively (Table 2$)$. The present findings are in line with the study results of [4] and [5].

The increased yield of clean coffee in the sole and staggered planting arrangement, it might be due to the increased population density of coffee trees, and the efficient utilization of the growth resources; viz., light, moisture, nutrients, etc. Similar result was observed in the previous works of [40], [41], [42], [43], [44], [45]. They reported that the efficient utilization of the growth resources by the individual coffee plant could be the possible reason for the yield increment. On the other hand, the mean clean coffee yield of the individual trees at an equal (1:1 coffee to enset) intercropped plot was higher compared with other combinations. However, the mean clean coffee yield per unit area decreased as the population density of the coffee and enset plants per unit area decreased and increased, respectively. Because, the coffee yield is highly correlated with the population density of the coffee trees per unit area as observed by the previous works of [44], [40], [46], [47], [48], [49].

\begin{tabular}{|c|c|c|c|c|}
\hline Treatments & 2013 & 2014 & 2015 & Pooled Mean \\
\hline Sole Coffee & $1142.70^{\circ}$ & $1072.33^{=}$ & $1429.60^{-1}$ & $1214.88^{\circ}$ \\
\hline Sole Enset & - & - & - & - \\
\hline $1 C=1 \mathrm{E}$ & $668.63^{c}$ & $792.83^{b}$ & $595.37^{\mathrm{d}}$ & $685.61^{\mathrm{d}}$ \\
\hline $2 C=1 E$ & $706.00^{\circ}$ & $799.30^{85}$ & $670.67^{\circ d}$ & $725.32^{\text {ed }}$ \\
\hline $3 C=1 \mathrm{E}$ & $835.37^{b c}$ & $822.07^{b}$ & $825.03^{c}$ & $827.49^{\circ}$ \\
\hline Staggered & $998.40^{\text {tb }}$ & $959.07^{\text {ab }}$ & $1027.07^{b}$ & $994.84^{b}$ \\
\hline LSD(0.0s) & $=$ & $*$ & $*$ & * \\
\hline CV $(\%)$ & 12.42 & 10.50 & 9.32 & 6.10 \\
\hline
\end{tabular}

\subsection{Enset}

Most of the enset growth parameters were not significantly affected by different ratios of intercropping with coffee throughout the study periods. However, results of enset yields namely kocho and bulla are 
shown in Table 3. The results showed intercropping of coffee with enset in different planting ratios significantly affect kocho and bulla yield $(\mathrm{P}<0.05)$. Both in the 2013 and 2015 cropping seasons, the sole enset showed significantly higher yields of kocho and bulla compared with the intercropped treatments (Table 3). This result could be associated with a high population density of enset plants in the sole plot. Among the intercropped plots, the highest kocho $\left(22,049 \& 20321 \mathrm{~kg} \mathrm{ha}^{-1}\right)$ yield was recorded from 1:1 coffee to enset intercropped plot in 2013 and 2015 cropping seasons, respectively. Similarly, the aforementioned treatment was also gave a higher bulla $\left(765.4 \& 629.6 \mathrm{~kg} \mathrm{ha}^{-1}\right)$ yield on the same cropping seasons.

In the pooled mean, the highest kocho $\left(21,185 \mathrm{~kg} \mathrm{ha}^{-1}\right)$ and bulla $\left(697.5 \mathrm{~kg} \mathrm{ha}^{-1}\right)$ were found in $1: 1$ coffee to enset mixture followed by $2: 1$ coffee to enset mixture $\left(17,954 \mathrm{~kg}_{\text {kocho }} \mathrm{ha}^{-1} \& 518.4 \mathrm{~kg}\right.$ bulla $\mathrm{ha}^{-1}$ ) (Table 3). The possible reason for the above results might be due to the high population density of enset plants per unit area compared with other intercrops, and less inter-specific competition between enset and coffee for below and above ground growth factors viz., moisture, nutrients, space, and light. At the same time, the relative yields of kocho and bulla in the intercropped plots linearly declined with the increasing of the population density of coffee trees (Fig. 2a\&b). This result is in line with the findings of other research studies of [4] and [5].

\begin{tabular}{|c|c|c|c|}
\hline Treatments & 2013 & 2015 & Pooled Mean \\
\hline \multicolumn{4}{|c|}{ Kacho Yield (Kg ha $\left.a^{-1}\right)$} \\
\hline Sole Coffee & - & - & - \\
\hline Sole Enset & $43000.00^{=}$ & $45333.00^{-1}$ & $44167.00^{=}$ \\
\hline $1 C=1 \mathrm{E}$ & $22049.00^{b}$ & $20321.00^{b}$ & $21185.00^{b}$ \\
\hline $2 C=1 E$ & $18805.00^{\mathrm{bc}}$ & $17104.00^{\mathrm{b}}$ & $17954.00^{\mathrm{bc}}$ \\
\hline $3 C=1 \mathrm{E}$ & $15314.00^{\text {od }}$ & $14438.00^{b}$ & $14876.00^{c}$ \\
\hline Staggered & $13464.00^{d}$ & $15642.00^{b}$ & $14553.00^{c}$ \\
\hline LSD(0.05) & 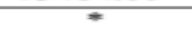 & + & $*$ \\
\hline CV $(\%)$ & 11.45 & 16.79 & 8.33 \\
\hline \multicolumn{4}{|c|}{ Bulla Yield (Kg hat $\left.{ }^{-1}\right)$} \\
\hline Sole Coffee & - & - & - \\
\hline Sole Enset & $1825.00^{\circ}$ & $1644.40^{\circ}$ & $1734.70^{a}$ \\
\hline $1 \mathrm{C}=1 \mathrm{E}$ & $765.40^{b}$ & $629.60^{b}$ & $697.50^{b}$ \\
\hline $2 C=1 E$ & $632.20^{\mathrm{b}}$ & $404.60^{b}$ & $518.40^{b c}$ \\
\hline $3 C=1 E$ & $435.20^{\mathrm{b}}$ & $369.50^{b}$ & $402.40^{\circ}$ \\
\hline Staggered & $445.80^{b}$ & $562.60^{\mathrm{b}}$ & $504.20^{\mathrm{be}}$ \\
\hline LSD(0.05) & $*$ & $*$ & $*$ \\
\hline CV $(\%)$ & 24.04 & 21.68 & 19.68 \\
\hline
\end{tabular}

\subsection{Land Equivalent Ratio (LER)}

In this study, the LER value was significantly $(\mathrm{P}<0.05)$ influenced by different intercropping ratios of coffee and enset crops. In the 2013 harvesting calendar, the higher LER values (>1) were observed in all intercropping mixtures. The highest values of LER 1.22 and 1.18 were observed in 1:1 coffee to enset and staggered mixtures, respectively (Table 4). In the 2015 harvesting calendar, the highest LER value was observed in staggered mixtures (1.35) followed by 1:1 coffee to enset mixture (1.02), while the value of 0.92 was observed in 2:1 coffee to enset mixture (Table 4). Likewise, the pooled mean value of LER in all intercropping mixtures was greater than one, indicating the advantage of intercropping mixtures over the sole stands of the component crops. Thus, the highest LER value (1.29) was observed in the staggered mixture followed by 1:1 coffee to enset intercropping mixture (1.19) (Table 4). These results might be attributed to more efficient total resource exploitation and greater overall production as opposed to the other intercrop combinations $[32,37,50]$.

On the other hand, it is also observed that the pooled mean value of LER in the intercrops ranged from 1.05 to 1.29 , which indicates an additional $29 \%$ of extra area of land would have been needed to get an equal yield to planting coffee and enset in pure stands. This result is in line with the findings of other research studies of [4] and [5] who demonstrated the advantage of coffee intercropping with enset, orange, potato and spice crops, as well as a higher value of LER $(>1)$ was also recorded. Similar results on different crops were also reported by several authors $[4,51,52,53]$.

\subsection{The Yield Advantage of Coffee}

The yield advantage of the intercrops was also determined along with the land equivalent ratio (LER) results. Based on the above-mentioned result, coffee and enset intercropping showed a higher yield advantage of coffee compared with the sole stand (Table 4). Besides, the yield advantage of coffee was also linearly increased along with the population density of coffee trees in the course of the study period. Thus, the best yield advantages of coffee $(0.87,0.89$, and 0.72$)$ were recorded from the treatment with a staggered planting arrangement in 2013, 2014, and 2015 harvesting calendar, respectively. In the pooled mean value, the highest yield advantage $(0.82)$ was recorded similarly from the aforementioned 
treatment (Table 4). The higher yield advantage of the intercrops over the sole stand might be resulted from the compatibility of the component crops for efficiently utilization of the growth resources viz., light, moisture and nutrients [43, 51, 53, 54 and 55]. In addition, the result could be associated with the different root and shoot structures of coffee and enset plants, which results different competitive ability of the component crops for growth resource utilization [21,56]. The findings of this study in agreement with the previous research works of [3], [4], [5] and [40].

\begin{tabular}{|c|c|c|c|}
\hline Treatments & 2013 & 2015 & Pooled Mean \\
\hline \multicolumn{4}{|c|}{ Land Equivalent Ratio (LER) } \\
\hline $1 \mathrm{C}=1 \mathrm{E}$ & 1.22 & 1.02 & 1.19 \\
\hline $2 \mathrm{C}=1 \mathrm{E}$ & 1.05 & 0.92 & 1.05 \\
\hline $3 C=1 \mathrm{E}$ & 1.08 & 0.99 & 1.07 \\
\hline Staggered & 1.18 & 1.35 & 1.29 \\
\hline \multicolumn{4}{|c|}{ Yield Advantage of Coffee } \\
\hline $1 \mathrm{C}=1 \mathrm{E}$ & 0.59 & 0.42 & 0.49 \\
\hline $2 \mathrm{C}=1 \mathrm{E}$ & 0.62 & 0.47 & 0.54 \\
\hline $3 C=1 E$ & 0.73 & 0.58 & 0.65 \\
\hline Staggered & 0.87 & 0.72 & 0.79 \\
\hline
\end{tabular}

\section{CONClusion}

The results of this study revealed that the potential benefits of coffee-enset intercropping for enhanced crop and land productivity. Also, it indicated the suitability and compatibility of the component crops for intercropping. Accordingly, the highest clean coffee yield advantage was observed in the staggered plot followed by 3:1 coffee to enset plot. The mean values of land equivalent ratios in all intercropped plots were greater than one, which indicates the efficient utilization of growth resources viz., moisture, nutrients, sun lights, space, etc. The highest and lowest values of LER were recorded in the staggered and 2:1 coffee to enset plots, respectively. Thus, the staggered planting ratio followed by $3: 1$ coffee to enset ratio could be the appropriate intercropping arrangement for enhancing the productivity of the component crops, and advisable for farmers in the study area. Nevertheless, additional studies are required in different agro-ecologies of the country with an economic feasibility analysis to deliver a concrete recommendation.

\section{ACKNOWLEDGMENTS}

We would like to thanks Ethiopian Institute of Agricultural Research (EIAR) for the financial support and Teppi Agricultural Research Center (TARC) for providing the experimental field for this study and also Mr. Asirade Chane, Mr. Wondifraw Derib, Mr. Wondimu Gebresillasie, Mr. Aschalew Bekele and Mr. Getenet Kassaye technical and field assistants of the agronomy research program at TARC during the study period for their unreserved support on fieldworks from land preparation up to data collection.

\section{REFERENCES}

[1] Abebe, T., Diversity in home garden agroforestry systems of Southern Ethiopia. PhD Dissertation, Wageningen University, Wageningen, Netherland, 153 (2005).

[2] Damenu, T., Coffee production and marketing in Oromiya. In: Girma, A., Bayetta, B., Tesfaye, S., Endale, T. and Taye, K. (Ed.). Coffee Diversity and Knowledge. Proceedings of a National Workshop Four Decades of Coffee Research and Development in Ethiopia, Addis Ababa, Ethiopia, 485 (2008).

[3] Kufa, T., Shimber, T. and Yilma, A., Intercropping coffee with sweet orange at Jimma Research center, Ethiopia. Journal of Cafe and Cacao, 5(1-2):17-21 (2004).

[4] Taye, K., Anteneh, N., Tesfaye, S., Endale, T. and Alemseged, Y., Intercropping coffee with other crops. In: Girma, A., Bayetta, B., Tesfaye, S., Endale, T. and Taye, K. (Ed.). Coffee Diversity and Knowledge. Proceedings of a National Workshop Four Decades of Coffee Research and Development in Ethiopia. Addis Ababa, Ethiopia, 485 (2008).

[5] Anteneh N., Taye K. and Tesfaye S., Review of Arabica Coffee Management Research in Ethiopia. Journal of Biology, Agriculture and Healthcare, 5(13):235-258 (2015).

[6] Ouma, G., Intercropping and its application to banana production in East Africa: A review. J. Plant Breed Crop Sci, 1:13-15 (2009).

[7] Van Asten P., Wairegi, L., Mukasa, D. and Uringi, N., Agronomic and economic benefits of coffee-banana intercropping in Uganda's smallholder farming systems. Agricultural Systems, 104:326-334 (2011).

[8] Kimemia, J., Effects of shade on the growth and yield of young Arabica coffee trees in Kenya. In Proceedings of the $20^{\text {th }}$ International Scientific Colloquium on Coffee. Bangalore, India, 11-15 (2004).

[9] Ratnadass, A., Fernandes, P., Avelino, J. and Habib, R., Plant species diversity for sustainable management of crop pests and diseases in agroforestry: A review paper. Agronomy and Sustainable Development, 32:273-303 (2012).

[10] Retnowarti, E., Sustainable development through complex agroforestry systems in Indonesia: Conference paper, XII world forestry congress, Quebec City, Canada (2003). 
[11] Côte, F., Tomekpe, K., Staver, C., Depigny, S., Lescot, T. and Markham, R., Agro-ecological intensification in banana and plantain: An approach to developing more sustainable cropping systems for both smallholder farmers and large-scale commercial producers. Acta Hort., 879:457-463 (2010).

[12] Chipungahelo, G., Teri, J., Matowo, P., Msaky, J., Magina, F., Malinga, S., Mbowe, D. and Kimaro, D., A review of coffee-banana based cropping systems in Tanzania: The economics. In: $20^{\text {th }}$ International Conference on Coffee Science (ASIC), Bangalore, India, 870-877 (2004).

[13] Vavilov N., The origin, variation, immunity, and breeding of cultivated plants. New York, Stechert-Hafner: Chronica Botanica. (1951)

[14] Temesgen, M., Bizuayehu, T., Marcello, C. and Mario, E., Indigenous knowledge, use and on-farm management of enset (Ensete ventricosum (Welw.) Cheesman) diversity in Wolaita, Southern Ethiopia. Journal of Ethnobiology and Ethnomedicine, 10(41):1-18 (2014).

[15] Belachew, G., Aklilu, A., Bewuketu, H. and Habtamu, K., Indigenous knowledge of Enset (Ensete ventricosum (Welw.) Cheesman) cultivation and management practice by Shekicho People, Southwest Ethiopia. Journal of Plant Sciences, 5(1):6-18 (2017).

[16] Hunduma, T., Sadessa, K., Hailu, E. and Oli, M., Evaluation of Enset clones resistance against Enset Bacterial Wilt Disease (Xanthomonas campestrispv. musacearum). J. Veterinary Sci, Technolo, 6(3):1-7 (2015).

[17] Ayele, A. and Omprakash S., Extension of Enset plant product for rural development in Ethiopia. Journal of Agricultural Economics, Extension and Rural Development: 2(3):031-040 (2014).

[18] Yemataw, Z., Mohamed, H., Diro, M. and Addis, T., Enset (Ensete ventricosum (Welw.) Cheesman) clone selection by farmers and their cultural practices in southern Ethiopia. Genetic Resources and Crop Evolution, 61(6):1091-1104 (2014).

[19] USAID (United States Agency for International Development), Staple Foods Value Chain Analysis. Country Report, Addis Ababa, Ethiopia (2010).

[20] Famaye, A.O., Evaluation of nutrient uptake in coffee intercropped with maize, cassava and plantain in Nigeria. Nigerian Journal of Applied Science, 23:1-5 (2005).

[21] Begum, S., Zaman, M. and Khan, A., Intercropping of root crops with chili in char lands of Mymensingh. Progressive Agriculture, 26:109-114 (2015)

[22] Dereje, G. and Eshetu, A., Agro-ecologies of Ethiopia and major crops grown. A research report in collaboration with Ethiopian Institute of Agricultural Research (EIAR). Addis Ababa, Ethiopia (2011).

[23] Girma, H., Digafe, T. and Wondyfraw, T., Yield and quality evaluation of ginger (Zingiber offcinale Rosc) collections and introductions. In: Lemma, D., Girma, H., Zenebe, W., Terefe, B., Asfaw, Z., Lakew, B. (Ed.) Ethiopian Horticultural Science Society (EHSS), Proceedings of the first inaugural conference, Addis Ababa, Ethiopia, 215-220 (2008).

[24] Abayneh, E. and Ashenaf, A., Soils of Tepi and Haru Agricultural Research Sub centers, soil survey and land evaluation section. National Soil Research Center. Ethiopian Institute of Agricultural Research, Addis Ababa, Ethiopia (2005).

[25] Murphy, H., A research report on fertility status and other data on some soils of Ethiopia. Experimental Station Bulletin, No. 44. Haile Silassie College of Agriculture, Oklahoma State University (1968).

[26] Tekalign, T., Soil, plant, water, fertilizer, animal manure and compost analysis. Working Document No. 13. International Livestock Research Center for Africa, Addis Ababa, Ethiopia (1991).

[27] Olsen, S., Cole, C., Watanabe, F. and Dean, L., Estimation of available phosphorus in soils by extraction with sodium bicarbonate. USDA Circular, Washington, USA 939:1-19 (1954).

[28] Hiebsch, C., Yield of Ensete ventricosum: A concept. In: T. Abate, C. Hiebsch, S. A. Brandt, \& S. Gebremariam (Eds.), Enset-based Sustainable Agriculture in Ethiopia. Proceedings from the International Workshop on Enset. Institute of Agricultural Research. Addis Ababa, Ethiopia, 15-35 (1996).

[29] Tsegaye, A. and Struik, P., Analysis of enset (Ensete ventricosum (Welw.) Cheesman) indigenous production methods and farm-based biodiversity in major enset-growing regions of southern Ethiopia. Experimental Agriculture, 38(3):291-315 (2002).

[30] Steven, A., Anita, S., Clifton, H., Terrence, J., Endale, T. et al., The “Tree Against Hunger" Enset-based agricultural systems in Ethiopia. American Association for the Advancement of Science with Awassa Agricultural Research Center Kyoto University Center for African Area Studies and University of Florida. Directorate for International Programs 1200 New York Av, NW Washington, DC 20005, 66 (1997).

[31] Willey, R., Evaluation and presentation of intercropping advantages. Experimental Agriculture, 21:119-133 (1985).

[32] Haruna, I., Aliyu, L. and Maunde, S., Competitive behavior of groundnut in sesame or groundnut intercropping system under varying poultry manure rates and panting arrangement. Sustainable Agriculture Research, 2:22-26 (2013).

[33] Ashish, D., Ista, D., Vineet, K., Rajveer, S., Mohit, Y. et al., Potential role of maize-legume intercropping systems to improve soil fertility status under smallholder farming systems for sustainable agriculture in India. Int. J. Life Sci. Biotech. Pharm. Res, 4(3):145-157 (2015).

[34] Jubaidur, R., Motiur, R., Zonayed-ull, A., Mukaddasul, I. and Fouzia, S. et al., Intermixed cropping of garden pea with onion. International Journal of Applied Research, 1(2):79-82 (2015). 
[35] Beyenesh, Z., Mereseit, H. and Haile, T., Maize and Potato Intercropping: A technology to increase productivity and profitability in Tigray. Research article. Open Agriculture, 2:411-416 (2017).

[36] Caballero, R., Goicoechea, E. and Hernaiz, P., Forage yield and quality of common vetch and oat sown at varying seed ratios and seeding rates of common vetch. Field Crops Research, 41:135-140 (1995).

[37] Zhang, G., Yang, Z. and Dong, S., Interspecific competitiveness affects the total biomass yield in an alfalfa and corn intercropping system. Field Crops Res., 124(1):66-73 (2011).

[38] Statistical Analysis System (SAS), SAS Institute, North Carolina, USA (2008).

[39] Gomez, K. and Gomez, A. Statistical procedure for agricultural research. International Rice Research Institute, Wiley-Inter science, 690 (1984).

[40] Taye, K., Tesfaye, S., Alemseged, Y., Anteneh, N., Endale, T., et al., The impact of close spacing on yield of Arabica coffee under contrasting agro-ecologies of Ethiopia. African Crop Sci, J., 9:401-409 (2001).

[41] Van der Vossen H., A critical analysis of the agronomic and economic sustainability of organic coffee production. Exp. Agric., 41:449-473 (2005).

[42] Hamdollah E., Intercropping of wheat (Triticum aestivum) and bean (Vicia faba): Effects of complementarity and competition of intercrop components in resource consumption on dry matter production and weed growth. African Journal of Biotechnology, 10(77):17755-17762 (2011).

[43] Paudel, M., Multiple cropping for raising productivity and farm income of small farmers. A review paper. Journal of Nepal Agricultural Research Council, 2:37-45 (2016).

[44] Mekonnen, B., Temeteme, S., Getachew, E., Kifelew, H. and Shimber, T., Determination of Appropriate Planting Space and Vertical Numbers for Hybrid Arabica Coffee at Yeki District, Southwestern Ethiopia. J. Hortic., 5:240 (2018).

[45] Shamim, A. and Mohammed, A., Intercropping short duration leafy vegetables with pumpkin in subtropical alluvial soils of Bangladesh. The South Pacific Journal of Natural and Applied Sciences, 36(1):27-35 (2018).

[46] Braccini, M., Braccini, A., Scapim, C., Vidigal, P. and Zabini, A., Grain production, concentration and utilization of nutrients in response to increase in planting density of coffee. Acta Scientiarum Agronomy, 24:12051211 (2002).

[47] DaMatta, F., Eco-physiological constraints on the production of shaded and unshaded coffee: A review. Field Crops Res., 86:99-114 (2004).

[48] Endale, T., Taye, K., Anteneh, N., Tesfaye, S., Alemseged, Y. and Tesfaye, A., Research on Arabica coffee field management. In: Girma, A., Bayetta, B., Tesfaye, S., Endale, T. and Taye, K. (Ed.). Coffee Diversity and Knowledge. Proceedings of a National Workshop Four Decades of Coffee Research and Development in Ethiopia. Addis Ababa (Ghion Hotel), Ethiopia, 485 (2008).

[49] Nigussie, A., Adugna, A., Ajema, L., Shimber, T. and Taye, E., Effects of planting density and number vertical on yield and yield component of south Ethiopia coffee selections at Awada, Sidama zone, Southern Ethiopia. Acad. Res. J. Agri. Sci. Res, 5(4):313-319 (2017).

[50] Thayamini H. and Brintha, I., Review on maize based intercropping. Journal of agronomy, 9(3):135-145 (2010).

[51] Agegnehu, G., Ghizaw, A. and Sinebo, W., Yield potential and land-use efficiency of wheat and faba bean mixed intercropping. Agron Sustain Dev, 28:257-263 (2008).

[52] Temesgen, D. and Wondimu, F., Performance of highland maize and potato varieties for intercropping in the western highlands of Ethiopia. Wudpecker Journal of Agricultural Research, 1(7):275-280 (2012).

[53] Yayeh, B., Determination of effective spatial arrangement for intercropping of maize and potato using competition indices at South Wollo, Ethiopia. International Journal of Research in Agriculture and Food Sciences, 2(8):09-19 (2014).

[54] Liu, J., Zeng, Z., Jiao, L., Hu, Y., Wang, Y. and Li, H., Intercropping of different silage maize cultivars and alfalfa. Acta Scientiarum Agronomy, 32:125-130 (2006).

[55] Shaker-Koohi, S., Nasrollahzadeh, S. and Raei, Y., Evaluation of chlorophyll value, protein content and yield of sorghum (Sorghum bicolor L.)/Mung bean (Vigna radiate L.) intercropping. International Journal of Biosciences, 4(8):136-143 (2014).

[56] Tsubo et al., 2001; Tsubo, M., Walker, S. and Mukhala, E., "Comparisons of radiation use efficiency of mono-/inter-cropping systems with different row orientations”. Field Crops Res., 71(1):17-29 (2001).

Citation: Behailu Mekonnen, et. al., "Intercropping of Coffee with Enset (Enset ventricosum Welw. Cheesman) at Teppi, Southwestern Ethiopia” International Journal of Research Studies in Agricultural Sciences (IJRSAS), 2020; 6(8), pp. 15-22, https://doi.org/10.20431/2454-6224.0608003

Copyright: (C) 2020 Authors. This is an open-access article distributed under the terms of the Creative Commons Attribution License, which permits unrestricted use, distribution, and reproduction in any medium, provided the original author and source are credited. 